\title{
Inheritance of the Average Weight of the Fruit in Tomato Hybrids with High Lycopene Content
}

\author{
Liudmila Andreevna Rudas ${ }^{1}$, Mariya Viktorivna Torbanyuk ${ }^{1, *}$, Zinovy Deonizovich Sych ${ }^{2}$ \\ ${ }^{1}$ Department of Crop, Cherkasy Research Station of the National Scientific Center «Institute of Agriculture of the National Academy of \\ Agrarian Sciences of Ukraine», Smila, Ukraine \\ ${ }^{2}$ Department of Genetics, Breeding and Seed Crops, Bila Tserkva National Agrarian University, Bila Tserkva, Ukraine
}

Email address:

mariyatr@ukr.net (M. V. Torbanyuk)

${ }^{*}$ Corresponding author

\section{To cite this article:}

Liudmila Andreevna Rudas, Mariya Viktorivna Torbanyuk, Zinovy Deonizovich Sych. Inheritance of the Average Weight of the Fruit in Tomato Hybrids with High Lycopene Content. American Journal of Agriculture and Forestry. Vol. 9, No. 2, 2021, pp. 69-75.

doi: 10.11648/j.ajaf.20210902.14

Received: February 23, 2021; Accepted: March 9, 2021; Published: March 17, 2021

\begin{abstract}
We studied five parental forms of tomato (Solanum Lycopersicum L.). Were obtained twenty $F_{l}$ hybrids by the complete diallel scheme $(5 \times 5)$ and used to study inheritance of the average weight of the fruit. Were used as parental forms in the system of diallel crosses according to Hayman V. I. and Jinks I. J.: the line №477 ( $s p$, $u$ ), variety Alya ( $s p$ ) and three collection samples with high lycopene content in fruits: Dark green $\left(h p-2^{d g}\right)$, MO $112(h p)$ and T-3627 $\left(B^{c}\right)$. The results of the evaluation are given of the general and specific combining ability of the five parental forms of tomato of the average weight of the fruit, established the character of inheritance. In the course of research it was found that the average weight of the fruit is controlled by the additive-dominant genetic system. Inheritance occurs by type of incomplete dominance. The main role in the genetic control of the trait is played by the additive effects of genes, which allows for selection, starting with the second hybrid generation. The direction of dominance varies from the dominance of genes that reduce the manifestation of the trait to its absence. The highest reliable effects of general combining ability (GCA) had the variety Alya, which must be used to create heterosis hybrids. From hybrid combinations with his participation in the future it is possible to make selections for creation of varieties.
\end{abstract}

Keywords: Combining Ability, Diallel Analysis, Tomato

\section{Introduction}

Tomato is one of the most nutritious vegetable crops in the world [1]. Modern medicine recommends tomato fruit as a therapeutic and dietary agent that increases the body's immune system, lowers cholesterol, prevents the development of diabetes and Alzheimer's disease. Carotenoids contained in tomatoes have anticancer properties [2-5]. All these qualities make tomato fruit an important component of the daily diet.

Tomato takes third place in world vegetable production. Leading producing countries are China, USA, India, Egypt, Turkey (FAO, 2006) [6].

Recently, there has been an increase in demand for tomato fruit consumption, both fresh and processed, which creates considerable space for the development of breeding to improve productivity and fruit quality [7]. Important indicators of productivity that are taken into account when selecting parental forms for breeding programs are the number of fruits per plant and the average weight of the fruit [8].

Highly pigmented forms with mutant genes $h p-2^{d g}, B^{o g}, B^{c}$ are a valuable material in the breeding for fruit quality, however, their characteristics are low productivity, late and extended ripening period, which significantly reduces the practical value [9-12]. Selection and involvement in crossing of early and high-yielding forms of a tomato allows to rececive a qualitative initial material which can be used in the further work for creation of heterosis hybrids and varieties [13-14].

To create a source material with a set of desirable economically valuable features, it is necessary to use a 
breeding material with a high general or specific combining ability. The best assessment of combining ability can be obtained by dialysis analysis [15-17]. It is also used to quickly obtain data on the nature of the inheritance of quantitative traits that are controlled by groups of genes (polygens) [18].

\section{Materials and Methods}

The purpose of this research is to identify parental forms with high general and specific combining ability and genetic analysis to establish genetic parameters and the character of inheritance of the average weight of the fruit.

The research was conducted in 2017-2019 in the fields of breeding and seed crop rotation of Cherkassy research station of the National Scientific Center «Institute of Agriculture of the National Academy of Agrarian Sciences of Ukraine», located in the village Kholodnyansky $\left(49^{0} 11^{\prime} \mathrm{N}\right.$ at $\left.31^{0} 52^{\prime} \mathrm{E}\right)$ Cherkassy region, Ukraine. For genetic analysis by (Hayman B. I., 1954; Jinks I. L., 1954) were used the line №477 ( $s p, u)$ and the variety Alya $(s p)$ with a reduced period of fruit ripening and three collection samples with high lycopene content in fruits: Dark green $\left(h p^{2 d g}\right)$, MO $112(h p)$ and $\mathrm{T}-3627\left(B^{c}\right)$.

The experiments are based on the method of one-factor experiments [19]. Evaluation of the combining ability of the average weight of the fruit was performed according to the first scheme Griffing $B$. I. with the matrix of crosses and test $p 2$ (direct and reciprocal crosses + parental forms), where $p$ - is the number of parental forms [15]. Genetic analysis was performed by Hayman V. I. and I. J. Jinks [17, 20].

\section{Results and Discussion}

Were found by analysis of variance in a one-factor experiment significant differences between hybrids. The average weight of the fruit is different, and the studied samples and varieties can be expected to differ in combining ability (general or specific) (Table 1).

Table 1. Analysis of variance of the average weight of the fruit.

\begin{tabular}{|c|c|c|c|c|c|c|}
\hline Years & Type of scattering & Sum of squares & Degree of freedom & Middle square & F calc. & F rabl. \\
\hline \multirow{5}{*}{2017} & General & 9643,5 & 74 & & \multirow{5}{*}{30,00} & \multirow{5}{*}{1,74} \\
\hline & Repetitions & 22,6 & 2 & & & \\
\hline & Options & 9019,6 & 24 & $375,82 *$ & & \\
\hline & Residual & 601,4 & 48 & 12,5 & & \\
\hline & $\mathrm{LSD}_{05}$ & & & 5,90 & & \\
\hline \multirow{5}{*}{2018} & General & 16534,5 & 74 & & \multirow{5}{*}{24,84} & \multirow{5}{*}{1,74} \\
\hline & Repetitions & 150,4 & 2 & & & \\
\hline & Options & 15163,0 & 24 & $631,79 *$ & & \\
\hline & Residual & 1221,1 & 48 & 25,4 & & \\
\hline & $\mathrm{LSD}_{05}$ & & & 8,40 & & \\
\hline \multirow{5}{*}{2019} & General & 8501,7 & 74 & & \multirow{5}{*}{16,05} & \multirow{5}{*}{1,74} \\
\hline & Repetitions & 28,9 & 2 & & & \\
\hline & Options & 7533,9 & 24 & $313,91 *$ & & \\
\hline & Residual & 938,9 & 48 & 19,6 & & \\
\hline & $\mathrm{LSD}_{05}$ & & & 7,37 & & \\
\hline
\end{tabular}

* Significant at 5\% level

The sum of squares in hybrids is due to genotypic differences. Parental line, variety and samples differed in the magnitude of the expression of the trait (Table 2).

Table 2. The average weight of the fruit of tomato in the parental samples, varieties ( $\bar{x} p)$ and hybrids $\left(\bar{x} F_{1}\right)$, days.

\begin{tabular}{|c|c|c|c|c|c|c|}
\hline \multirow{3}{*}{ Sample } & \multicolumn{6}{|c|}{ Years of research } \\
\hline & \multicolumn{2}{|c|}{2017} & \multicolumn{2}{|l|}{2018} & \multicolumn{2}{|l|}{2019} \\
\hline & $\mathbf{P}$ & $\mathbf{F}_{1}$ & $\mathbf{P}$ & $\mathbf{F}_{1}$ & $\mathbf{P}$ & $\mathbf{F}_{1}$ \\
\hline №477 & 70,5 & 69,2 & 84,5 & 88,0 & 42,7 & 56,0 \\
\hline Alya & 96,8 & 83,8 & 133,1 & 111,7 & 88,7 & 73,0 \\
\hline Dark green & 46,5 & 61,6 & 80,2 & 88,7 & 46,5 & 59,2 \\
\hline MO 112 & 68,6 & 67,1 & 82,1 & 87,9 & 55,8 & 59,9 \\
\hline $\mathrm{T}-3627$ & 71,7 & 70,2 & 84,8 & 91,6 & 55,6 & 58,7 \\
\hline$x$ & 70,8 & 70,4 & 92,9 & 93,6 & 57,9 & 61,3 \\
\hline $\mathrm{LSD}_{05}$ & 5,90 & & 8,40 & & 7,37 & \\
\hline
\end{tabular}

The largest weight of the fruit was the variety Alya (88.0$133.1 \mathrm{~g})$, the lowest value of the trait was in the samples
Dark green (46.5-80.2 g) and the №477 (42.7-84.5 g). Insignificant differences between group average parents and hybrids for all years of research indicate the intermediate character of the inheritance of the trait. The average values of the weight of the fruit in hybrids with the participation of the variety Alya are the largest and are 83.8-111.7, and with the participation of the samples №477, Dark green, MO 112, T3627 less than the group average for parental forms for three years research. The difference between the average $F_{1}$ and the parental forms in 2018 and 2019 is positive (insignificant differences) and negative in 2017 (insignificant differences), that is, less expression of the trait dominates.

The results of the analysis of variance of the combining ability (Table 3) indicate significant differences in general and specific combining ability. In addition, for two years of research (in 2018 and 2019) was found a significant reciprocal effect. 
Table 3. Analysis of variance of the combining ability of the average weight of the fruit.

\begin{tabular}{lllllll}
\hline Years & $\begin{array}{l}\text { Type of } \\
\text { scattering }\end{array}$ & $\begin{array}{l}\text { Sum of } \\
\text { squares }\end{array}$ & $\begin{array}{l}\text { Degrees of } \\
\text { freedom }\end{array}$ & $\begin{array}{l}\text { Middle } \\
\text { square }\end{array}$ & $\begin{array}{l}\text { F } \\
\text { calc. }\end{array}$ & $\begin{array}{l}\text { F } \\
\text { tabl. }\end{array}$ \\
\hline \multirow{6}{*}{2017} & Hybrids & 8788,4 & 24 & $366,2^{*}$ & 26,3 & 1,79 \\
& GCA & 2605,2 & 4 & $651,3^{*}$ & 140,4 & 2,61 \\
& SCA & 263,0 & 10 & $26,3^{*}$ & 5,7 & 2,08 \\
& Reciprocals & 61,3 & 10 & $6,1^{*}$ & 1,3 & 2,08 \\
& Residual & 222,7 & 48 & $4,6^{*}$ & & \\
& Hybrids & 15163,0 & 24 & $631,8^{*}$ & 24,8 & 1,79 \\
& GCA & 4188,5 & 4 & $1047,1^{*}$ & 123,5 & 2,61 \\
2018 & SCA & 595,3 & 10 & $59,5^{*}$ & 7,0 & 2,08 \\
& Reciprocals & 270,6 & 10 & $27,1^{*}$ & 3,2 & 2,08 \\
& Residual & 407,0 & 48 & $8,5^{*}$ & & \\
& Hybrids & 7535,1 & 24 & $314,0^{*}$ & 16,1 & 1,79 \\
& GCA & 1817,3 & 4 & $454,3^{*}$ & 69,7 & 2,61 \\
& SCA & 556,9 & 10 & $55,7^{*}$ & 8,5 & 2,08 \\
& Reciprocals & 137,5 & 10 & $13,8^{*}$ & 2,1 & 2,08 \\
& Residual & 312,9 & 48 & $6,5^{*}$ & & \\
\hline
\end{tabular}

* Significant at $5 \%$ level

Studies have shown that the average weight of the fruit for the best reliable effects of general combining ability (GCA) for three years of research had a variety of Alya (from 11.69 to 18.11) (Table 4).

Table 4. Evaluation of the effects of general combining ability (GCA) of the average weight of the fruit.

\begin{tabular}{llll}
\hline \multirow{2}{*}{ Sample } & Years & \\
\cline { 2 - 4 } & $\mathbf{2 0 1 7}$ & $\mathbf{2 0 1 8}$ & $\mathbf{2 0 1 9}$ \\
\hline №477 & $-1,28^{*}$ & $-5,57^{*}$ & $-5,67^{*}$ \\
Alya & $13,26^{*}$ & $18,11^{*}$ & $11,69^{*}$ \\
Dark green & $-8,58^{*}$ & $-4,87^{*}$ & $-2,09^{*}$ \\
MO 112 & $-3,04^{*}$ & $-5,68^{*}$ & $-1,38$ \\
T-3627 & $-0,36$ & $-1,98^{*}$ & $-2,54^{*}$ \\
LSD $_{05}$ & 5,90 & 1,66 & 1,45 \\
\hline
\end{tabular}

* Significant at $5 \%$ level

Significant negative values of the effects of general combining ability (GCA) during the three years of research (from minus 2.09 to minus 8.58 ) and (from minus 1.28 to minus 5.67), respectively, had samples Dark green and №477. Samples MO 112 and T-3627 had significant negative values of the effects of GCA for two years of research.

Significant differences in specific combining ability (SCA) over the years of research indicate that some hybrid combinations within the variety differed significantly from its average value, and non-additive effects of genes are involved in the inheritance of the trait. In order to identify samples and varieties with high or low specific combining ability (SCA), for each parent form, we calculated the variance for comparison with the overall average value (Table 5).

We found that high reliable values of specific combining ability (SCA) for three years of research were in the sample №477 (6.45-34.77), for two years of research in the variety Alya (6.73-45.58), for one year - in samples MO 112 (6.38), Dark green (31.97) and T-3627 (20.94). The best values of
SCA were in hybrid combinations: for two years of research: №477 / Dark green (5.36-11.52); for one year of research: Alya / T-3627 (9.90); №477 / Alya (4.36); №477 / MO 112 (4.9); Dark green / T-3627 (4.03); Dark green / MO112 $(3,58)$.

Comparison of the variance of the effects of general $\left(\delta_{g_{1}}{ }^{2}\right)$ and specific $\left(\delta_{S i}{ }^{2}\right)$ combining ability revealed that in the variety Alya (highest average weight of the fruit, high reliable effects of SCA), sample MO 112 for three years of research, sample Dark green (lowest average weight of the fruit, low negative significant effects of SCA) during two years of research observed the predominance of additive effects of genes in genetic control of the trait.

Table 5. Estimation of variances of general combining ability (GCA) and specific combining ability (SCA) at an estimation of samples and varieties of the average weight of the fruit of 2017-2019.

\begin{tabular}{|c|c|c|c|c|c|c|c|}
\hline $\begin{array}{l}\text { Variety, } \\
\text { Sample }\end{array}$ & Years & Alya & $\begin{array}{l}\text { Dark } \\
\text { green }\end{array}$ & $\begin{array}{l}\text { MO } \\
112\end{array}$ & T-3627 & $\delta_{S i}{ }^{2}$ & $\delta_{g_{1}}^{2}$ \\
\hline \multirow{3}{*}{ № 477} & 2017 & $4,33^{*}$ & $-1,40$ & $-1,38$ & $-4,14 *$ & $6,45^{*}$ & 1,04 \\
\hline & 2018 & $-9,65^{*}$ & $5,36^{*}$ & $4,90 *$ & $-2,70$ & $31,90 *$ & 29,92 \\
\hline & 2019 & $-5,04^{*}$ & $11,52 *$ & 0,73 & 0,03 & $34,77 *$ & 31,30 \\
\hline \multirow{3}{*}{ Alya } & 2017 & & 0,64 & $-4,65^{*}$ & $-0,07$ & $6,73 *$ & 175,23 \\
\hline & 2018 & & 0,50 & $-4,05^{*}$ & $9,90 *$ & $45,58^{*}$ & 326,87 \\
\hline & 2019 & & $-2,70$ & 0,86 & 2,88 & 5,54 & 135,81 \\
\hline \multirow{3}{*}{$\begin{array}{l}\text { Dark } \\
\text { green }\end{array}$} & 2017 & & & $3,58 *$ & $4,03 *$ & 4,38 & 73,02 \\
\hline & 2018 & & & $-0,29$ & $-1,90$ & 1,80 & 22,62 \\
\hline & 2019 & & & 2,59 & $-0,83$ & $31,97 *$ & 3,52 \\
\hline \multirow{3}{*}{ MO 112} & 2017 & & & & $-1,74$ & $6,38^{*}$ & 8,64 \\
\hline & 2018 & & & & $-0,48$ & 3,81 & 31,16 \\
\hline & 2019 & & & & $-1,51$ & $-2,33$ & 1,05 \\
\hline \multirow{3}{*}{ T-3627 } & 2017 & & & & & 5,62 & $-0,47$ \\
\hline & 2018 & & & & & $20,94 *$ & 2,82 \\
\hline & 2019 & & & & & $-2,07$ & 5,60 \\
\hline \multirow{3}{*}{$\begin{array}{l}\text { Average } \\
\text { value }\end{array}$} & 2017 & & & & & 5,91 & \\
\hline & 2018 & & & & & 20,81 & \\
\hline & 2019 & & & & & 13,58 & \\
\hline
\end{tabular}

* Significant at $5 \%$ level

Note. $\delta_{S i}{ }^{2}$ - variance of the effect of specific combining ability; $\delta_{g_{1}}{ }^{2}$ variance of the effect of general combining ability.

For three years of research was established the predominance of non-additive effects of genes in the sample №477 and for two years - in the sample T-3627. Thus, it was found that in most cases in genetic control traits are dominated by additive effects of genes, which makes it possible to make selections starting from the second hybrid generation. The variety Alya with high general combining ability (GCA) effects should be used to create heterosis hybrids. From the above-mentioned hybrid combinations with its participation in the future it is possible to make selections for creation of varieties.

Genetic analysis by (Hayman B. I., 1954) checks the homogeneity of the difference between covariance and variance of $W r-V r$ through Student's $t$ test did not reveal epistatic interaction of genes. Was constructed a graph of the dependence of $W r$ on $V r$ according to the indicators of variance and covariance (Figure 1). Graphic analysis shows 
that the inheritance of the average weight of the fruit, involved additive and non-additive effects of genes (the regression coefficients are reliable and do not differ from one), that is, the regression line does not deviate from the unit slope line. This is confirmed by the high significance of the components $D$ and $H 1$, which characterize the variability of the trait, which is due to the additive and dominant effects of genes (Table 6).

Table 6. Genetic parameters of the average weight of the fruit.

\begin{tabular}{llll}
\hline \multirow{2}{*}{ Parameters } & \multicolumn{3}{l}{ Years } \\
\cline { 2 - 4 } & $\mathbf{2 0 1 7}$ & $\mathbf{2 0 1 8}$ & $\mathbf{2 0 1 9}$ \\
\hline $\mathrm{D}$ & $313,32 \pm 5,15^{*}$ & $498,70 \pm 21,69^{*}$ & $322,83 \pm 29,54^{*}$ \\
$\mathrm{~F}$ & $70,53 \pm 12,87^{*}$ & $90,64 \pm 54,17^{*}$ & $172,21 \pm 73,80^{*}$ \\
$\mathrm{H}_{1}$ & $62,90 \pm 13,09^{*}$ & $116,28 \pm 55,12^{*}$ & $132,06 \pm 75,09^{*}$ \\
$\mathrm{H}_{2}$ & $43,32 \pm 12,62^{*}$ & $102,11 \pm 53,12^{*}$ & $98,35 \pm 72,37^{*}$ \\
$\mathrm{~h}^{2}$ & $0,62 \pm 8,52^{*}$ & $9,36 \pm 35,86^{*}$ & $413,16 \pm 48,86^{*}$ \\
$\mathrm{E}$ & $4,64 \pm 2,10^{*}$ & $8,48 \pm 8,85^{*}$ & $6,52 \pm 12,06^{*}$ \\
$\mathrm{H}_{1} / \mathrm{D}$ & 0,20 & 0,23 & 0,41 \\
$\sqrt{\mathrm{H}_{1} / \mathrm{D}}$ & 0,45 & 0,48 & 0,64 \\
$\mathrm{H}_{2} / 4 \mathrm{H}_{1}$ & 0,17 & 0,22 & 0,19 \\
$\sqrt{4 D H 1+F}$ & 0,67 & 1,46 & 2,43 \\
\hline$\sqrt{4 D H 1-F}$ & 0,01 & 0,09 & $4,20 *$ \\
$\mathrm{~h}^{2} / \mathrm{H}_{2}$ & 81,33 & 83,31 & 13,89 \\
Conditionally dominant \\
$(\mathrm{CD})$ & & 107,22 & 163,88 \\
Conditionally recessive & 53,98 & & \\
(CR) & & & 0.46 \\
\hline
\end{tabular}

The uneven ratio of genes with positive and negative effects is indicated by the ratio of $H 2 / 4 H 1$, which was 0.17 0.22 . The parameter $\frac{\sqrt{4 D H 1+F}}{\sqrt{4 D H 1-F}}$ in 2018 and 2019 varied in the range of 1.46-2.43, which indicates an excess of dominant gene alleles in the studied samples; in $2017-0.67$, which indicates an excess of recessive alleles. The value of parameter $D$, which measures additive variability in the population, was higher than that of $H 1$, which measured dominant variability over three years of research. Values $H 1>H 2$, which indicates an unequal ratio of positive and negative effects.

Positive significant values of the indicator $F \quad(F>0)$ indicate the predominance of dominant alleles in the set of varieties and samples studied. For three years of research, the average degree of dominance was $0.45-0.64$. The regression line intersects the positive part of the $W r$ axis, so we can talk about incomplete dominance at all loci. The parameter $h 2 / H 2$ indicates the number of groups of genes (more precisely, the number of effective factors) that show dominance and control the genotypic variation of the trait. It is determined with a significant difference in the parameters $h 2 / H 2$. Such a difference existed only in 2019, which allowed us to calculate the value of this indicator, which is 4.2 . That is, the studied variety and samples differ in four groups of genes that show the effect of dominance.

The table 7 shows the indicators of the genetic component $F$, which reflects the relative contribution of additive and dominant effects of genes in the phenotypic manifestation of the trait in $F_{l}$ hybrids.

Table 7. Estimation of the direction of dominance $(F)$ of the average weight of the fruit of tomato for each parental forms and their hybrids.

\begin{tabular}{|c|c|c|c|}
\hline \multirow{2}{*}{ Samples } & \multicolumn{3}{|l|}{ Years } \\
\hline & 2017 & 2018 & 2019 \\
\hline №477 & $-70,66 \pm 17,53 *$ & $558,41 \pm 73,77 *$ & $254,24 \pm 100,50 *$ \\
\hline Alya & $83,38 \pm 17,53 *$ & $-158,18 \pm 73,77^{*}$ & $15,13 \pm 100,50 *$ \\
\hline Dark green & $-89,28 \pm 17,53 *$ & $104,32 \pm 73,77 *$ & $245,41 \pm 100,50 *$ \\
\hline MO112 & $280,29 \pm 17,53 *$ & $325,14 \pm 73,77 *$ & $213,88 \pm 100,50 *$ \\
\hline $\mathrm{T}-3627$ & $148,91 \pm 17,53 *$ & $-376,50 \pm 73,77^{*}$ & $132,41 \pm 100,50 *$ \\
\hline
\end{tabular}

* Significant at $5 \%$ level

Significant positive effects for three years of research were observed in the sample MO 112, for two years of research in the sample №477, variety Alya, samples Dark green and T3627 , which indicates the predominance of dominant alleles. Recessive alleles predominated in 2017 in the samples №477 and the Dark green, in 2018 - the Alya variety.

High correlation coefficients between covariance $(\mathrm{Wr})$ and variance $(V r)$, as well as regression coefficients $b_{l}$ between $W r$ and $V r$ (Table 8) indicate that the actual regression lines do not differ significantly from the unit slope.

Table 8. The results of correlation and regression analyzes of the average weight of the fruit of tomato.

\begin{tabular}{llll}
\hline Indicator & $\mathbf{2 0 1 7}$ & $\mathbf{2 0 1 8}$ & $\mathbf{2 0 1 9}$ \\
\hline Correlation $(r)$ between $W r$ and $V r$ & 0,99 & 0,96 & 0,41 \\
Regression $\left(b_{1}\right)$ between $W r$ and $V r$ & 1,11 & 0,95 & 1,10 \\
Correlation $(r)$ between $\bar{x} p$ and $W r$ and $V r$ & $-0,38$ & 0,38 & 0,95 \\
Regression $\left(b_{2}\right)$ between $\bar{x} p$ and $W r$ and $V r$ & $-0,09$ & 0,05 & 0,34 \\
\hline
\end{tabular}

The correlation coefficient between the average values on the trait in the parents $(x p)$ and the sum $(W r+V r)$ was positive in 2018 and 2019 and was 0.98 and 0.38 .

The positive value of the correlation coefficient indicates the existence of a relationship between of the average weight of the fruit in the samples and varieties and the presence of recessive genes (the parental forms with the highest weight of the fruit have the highest number of recessive alleles). Indicators of high positive correlation, recessive genes determine the increase in trait, that is, in this case, the increase in the average weight of the fruit is controlled by recessive alleles.

With the participation of the correlation coefficient between the average values of the trait of parental forms in the parents $(\bar{x} p)$ and the sum $(W r+V r)$ determined the theoretical values $W_{d o m}+V_{d o m}$ and $W_{\text {rec }}+V_{\text {rec }}$ for varieties and samples, which have dominant and recessive alleles. This allowed us to predict their breeding value. The variety or sample, which theoretically has all the dominant alleles of the studied parental forms will have $W_{d o m}+V_{d o m} 81.33$ (2017), 83.31 (2018) and 13.89 (2019). The theoretical value of the parental form with the largest number of recessive genes was 53.98 (2017), 107.22 (2018) and 168.88 (2019). As can be seen, all the studied samples have the value of a feature that differs from the theoretical. 
Using regression graphs (Figure 1), we obtained more and recessive effects. complete information about the manifestation of dominant

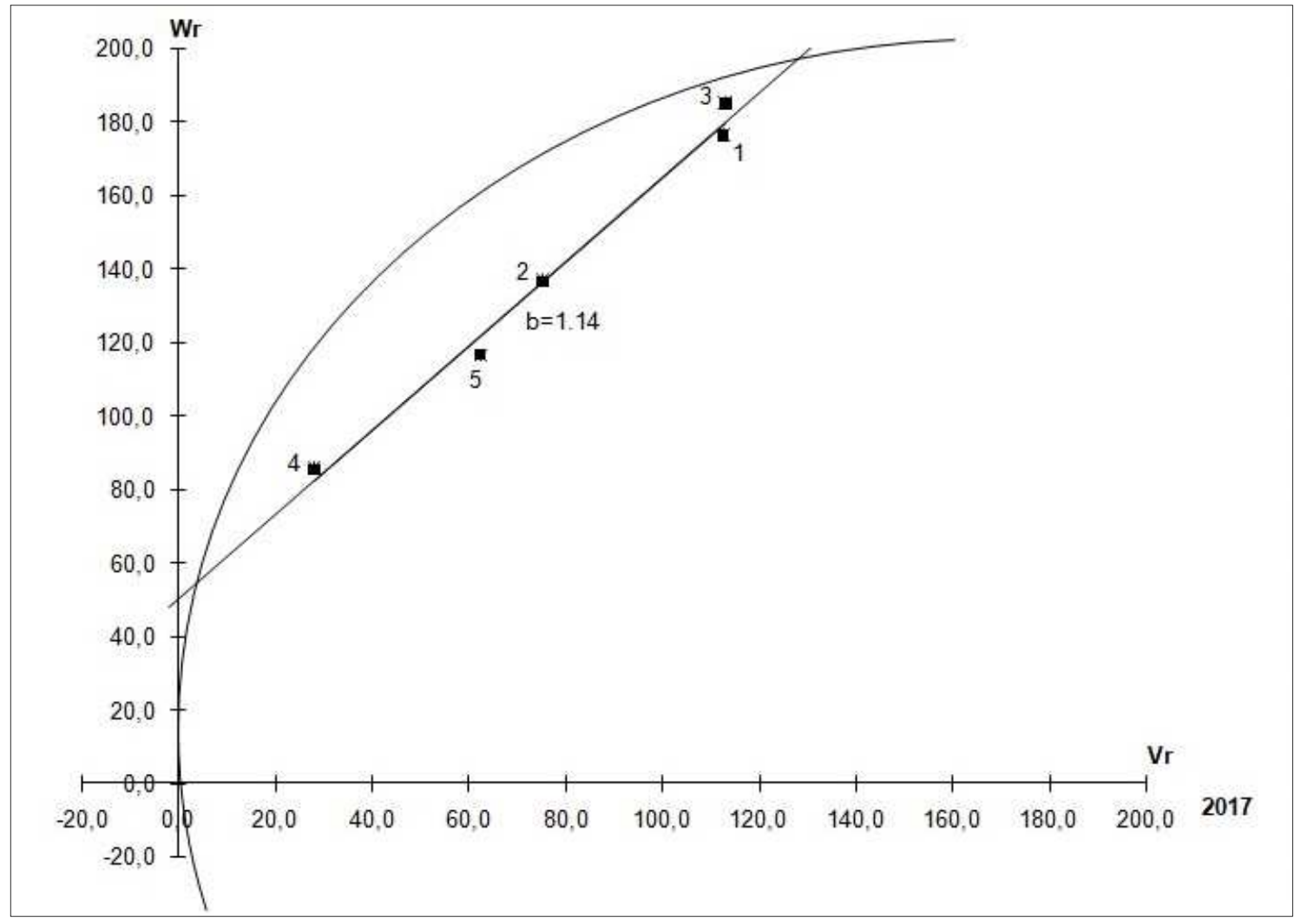

a) 2017

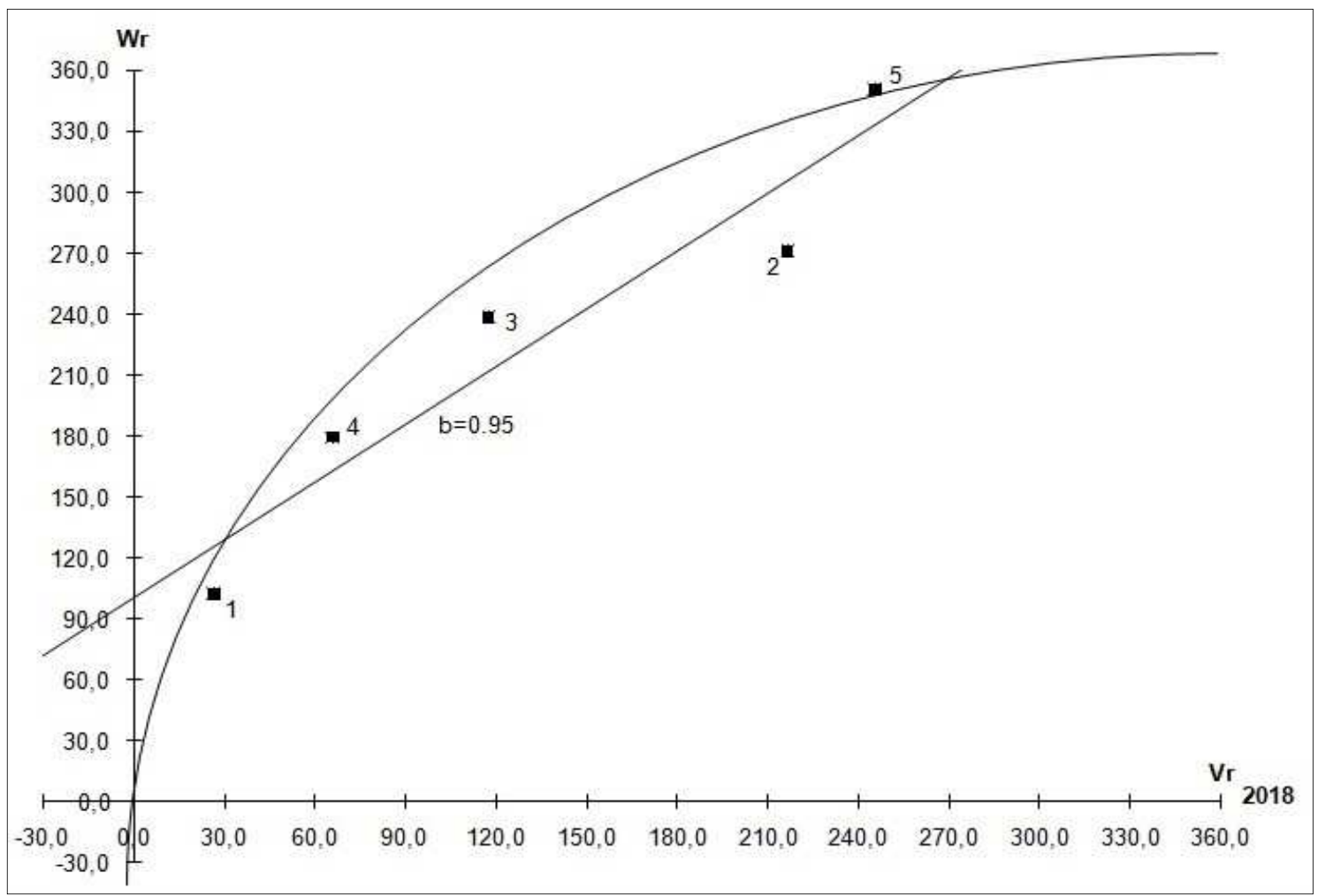

b) 2018 


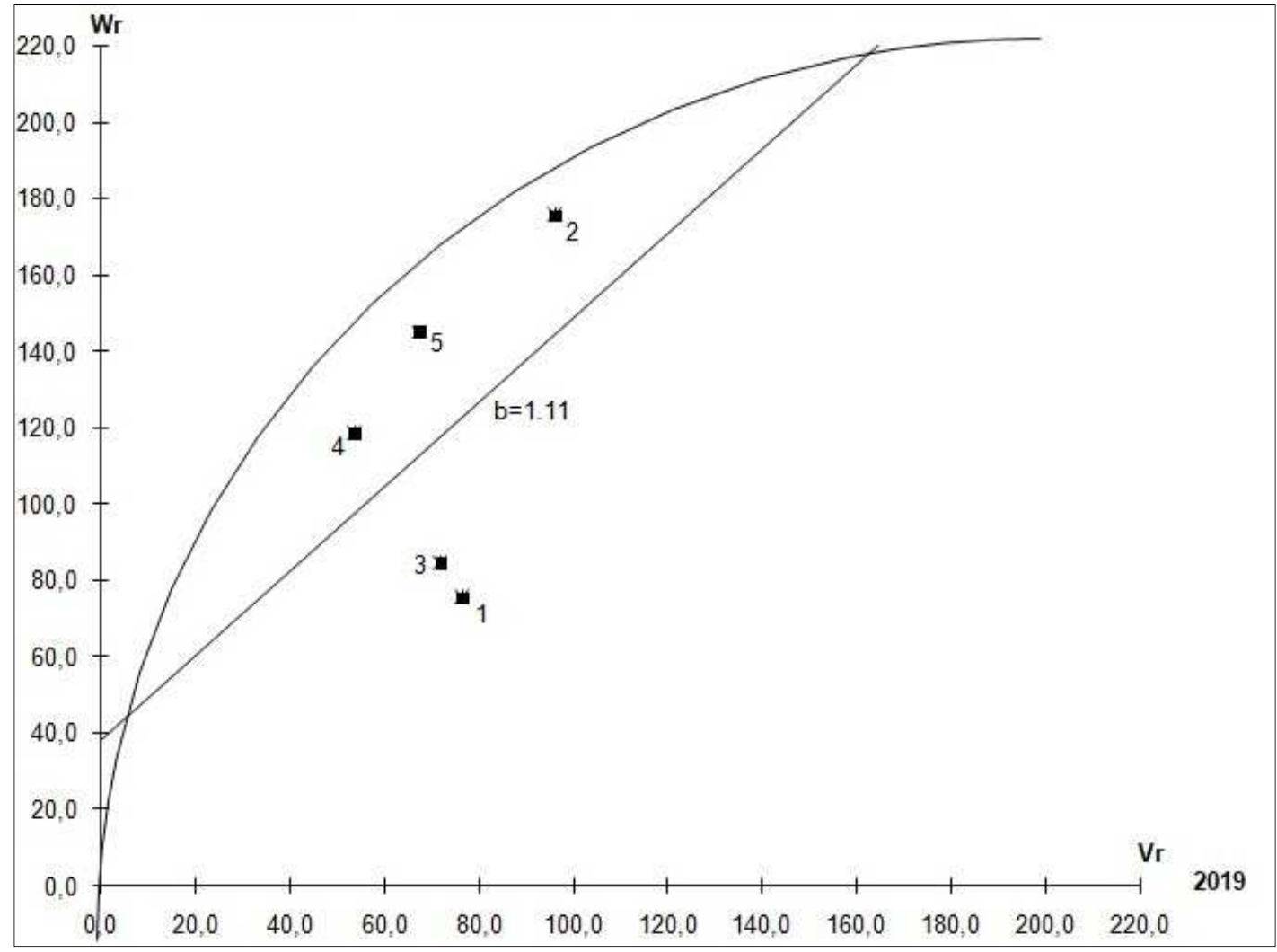

c) 2019

Figure 1. The graph of dependence Wr by $\mathrm{Vr}$.

1 - Line №477; 2 - Variety Alya; 3 - Sample Dark green;

4 - Sample MO 112; 5 - Sample T-3627.

In 2017, according to the $F_{1}$ assessment, the samples MO 112 and T-3627 approached the point with the maximum dominance. Samples Dark green and №477, which had 75 percent recessive alleles, approached the point with the highest recessiveness. The point of the variety Alya is located in the middle of the regression line.

In 2018, the placement of varieties and samples on the regression chart changed. Samples MO 112 and T-3627, which had 100 percent dominant alleles, were located in the zone with the highest dominance. Points of variety Alya and sample T-3627 were located in the zone of greatest recessiveness and had, respectively, 50 and $75 \%$ of recessive alleles. The point of the sample Dark green was located in the middle region of the regression line.

In 2019, the points of the four parental forms were located in the zone of greatest dominance: samples №477, Dark green, MO 112 and T-3627. The point of the variety Alya lies in the middle region of the regression line, far from the points of intersection of the parabola with the regression line.

\section{Conclusions}

Genetic analysis to establish that of the average weight of the fruit is controlled by the additive-dominant genetic system. The main role in the genetic control of the trait is had by the additive effects of genes, which allows the selection of the phenotype, starting with the second hybrid generation. Inheritance occurs by type of incomplete dominance. The direction of dominance varies from the dominance of genes that reduce the manifestation of the trait to its absence.

Studies have shown that of the average weight of the fruit the best reliable effects of general combining ability (GCA) for three years of research had a variety Alya (from 11.69 to 18.11). It can be recommended for the creation of heterosis hybrids and varieties. From hybrid combinations with the participation of the variety Alya, we conducted selections for the creation of varieties.

\section{References}

[1] Shabbir, A., Mao, H., Ullah, I., Buttar, N. A., Ajmal, M., Lakhiar, I. A. (2020). Effects of Drip Irrigation Emitter Density with Various Irrigation Levels on Physiological Parameters, Root, Yield and Quality of Cherry Tomato. Agronomy, $\quad 10 \quad$ (11), $1685 . \quad$ DOI: https://doi.org/10.3390/agronomy10111685.

[2] Dūma, M., Alsina, I., Dubova, L., Erdberga, I. (2018). Bioactive compounds in tomatoes at different stages of maturity. Proceedings of the Latvian Academy of Sciences. Section B. Natural, Exact, and Applied Sciences, 72 (2), 8590. DOI: https://doi.org/10.2478/prolas-2018-0014. 
[3] Speer, H., D’Cunha, N. M., Alexopoulos, N. I., McKune, A. J., Naumovski, N. (2020). Anthocyanins and Human HealthA Focus on Oxidative Stress, Inflammation and Disease.

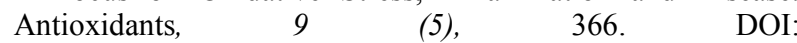
https://doi.org/10.3390/antiox9050366

[4] Di Gioia, F., Tzortzakis, N., Rouphael, Y., Kyriacou, M. C., Sampaio, S. L., C. F. R. Ferreira, I., Petropoulos, S. A. (2020). Grown to Be Blue-Antioxidant Properties and Health Effects of Colored Vegetables. Part II: Leafy, Fruit and Other Vegetables. Antioxidants, 9 (2), 97. DOI: https://doi.org/10.3390/antiox9020097.

[5] Arya, M. S., Beaulah, A. and Syama, S. Thampi. (2019). Evaluation and selection of superior tomato genotypes for high antioxidant composition. Journal of Pharmacognosy and Phytochemistry, 8 (2), 1912-1915.

[6] FAO (2006) FAO production Yearbook, Basik Data Unit, Statistics Division, Rome, Italy, 55, 125-127.

[7] Nemeskéri, E., Neményi, A., Bőcs, A., Pék, Z., Helyes, L. (2019). Physiological Factors and their Relationship with the Productivity of Processing Tomato under Different Water Supplies. Water, $11 \quad$ (3), $586 . \quad$ DOI: https://doi.org/10.3390/w11030586.

[8] Stevens, M. A., Rick, C. M. (1986). Genetics and Breeding. New York, USA: Chapman \& Hall. 240p.

[9] Pal, H., Sahu, R., Sethi, A., Hazra, P., Chatterjee, S. (2019). Unraveling the metabolic behavior in tomato high pigment mutants (hp-1, hp- $\left.2^{\mathrm{dg}}, \mathrm{ogc}\right)$ and non ripening mutant (rin) during fruit ripening. Scientia Horticulturae, 246, 652-663. DOI: https://doi.org/10.1016/j.scienta.2018.11.047.

[10] Levin, I., Frankel, P., Gilboa, N., Tanny, S. \& Lalazar, A. (2003). The tomato dark green mutation is a novel allele of the tomato homolog of the DEETIOLATED1 gene. Theoretical and Applied Genetics, 106, 454-460.

[11] Bino, R. J., C. H. de Vos., Lieberman, M., Hall, R. D., Bovy, A., Jonker, H. H., Tikunov, Y., Lommen, A., Moco, S., Levin,
I. (2005). The light-hyperresponsive high pigment-2 mutation of tomato: Alterations in the fruit metabolome. New Phytologist, 166, 427-438. https://doi.org/10.1111/j.1469-8137.2005.01362.x

[12] Ilahy, R., Siddiqui, M. W., Piro, G., Lenucci, M. S., Hdider, C., Helyes, L. (2017). A focus on high-lycopene tomato cultivars: horticultural performance and functionalquality. ActaHorticulturae, 1159, 57-64. DOI: https://doi.org/10.17660/ActaHortic.2017.1159.9.

[13] Gautam, N., Kumar, M., Kumar, S., Vikram, A., Dogra, R. K. and Bharat, N. (2016). Combining ability analysis and gene action for yield and its contributing traits in tomato (Solanum lycopersicum L.) under North Western Himalayan region. Ecology Environment and Conservation, 22 (1), 345-349.

[14] Gautam, N., Kumar, M., Vikram, A., Kumar, S., Sharma, S. (2018). Heterosis studies for yield and its components in tomato (Solanum lycopersicum L.) under north western Himalayan region, India. International journal of current microbiology and applied science, 7 (2), 1949-1957. DOI: https://doi.org/10.20546/ijcmas.2018.702.234.

[15] Griffing, B. (1956). Concept of general and specific combining ability in relation to diallel crossing systems. Australian journal of biological sciences, 9, 463-493.

[16] Yates, F. (1947). Analysis of data from all possible reciprocal crosses between a set of parental lines. Heredity, 1, 287-301.

[17] Hayman, B. I. (1954). The theory and analysis of diallel crosses. Genetics, 39 (6), 789-809.

[18] Fedin, M. A. (1970). About heterosis of wheat. Moscow, Kolos, 240p. [Ru].

[19] Dospehov, B. A. (1985). Methodology of field experience (with principles of statistic treatment for results of researches). Agroproizdat, Moscow, 352 p. [Ru].

[20] Jinks, I. L. (1954). The analysis of continuous variation in a diallel cross of Nicotiana rustica varieties. Genetics, 39 (6), 767-788. 